\title{
Influence of Nanocomposite Scaffolds Using Freeze-drying Technique on Hepg2
}

\author{
M.I. El Gohary ${ }^{(1)}$, Gehan M. Kamal(2), E. Meliegy( ${ }^{(3)}$, S.M. Awad ${ }^{(2)}$, Asmaa M. \\ El-Tohamy ${ }^{(2)}$ \\ ${ }^{(1)}$ Biophysics branch, Physics Department, Faculty of Science, Al-Azhar \\ University(boys), Nasr City 11884, Cairo, Egypt. ${ }^{(2)}$ Biophysics branch, Physics \\ Department, Faculty of Science, Al-Azhar University(girls), Nasr City 11884, Cairo, \\ Egypt. ${ }^{(3)}$ Ceramics and Building materials Dept., National Research Centre, 12622 \\ El-Tahrir street, Dokki, Cairo.
}

\begin{abstract}
TOVEL approaches are devoted towards creating 3D scaffolds that allow good permeability 1 and diffusion. Appropriate synthetic biodegradable materials for this purpose are biopolymer- bioceramic nanocomposites. They have good tissue compatibility and safety profiles seem essential for their successful utilization in medical applications. The 3D dicalcium phosphate/dextran/ sodium carboxymethyl cellulose nanocomposites are prepared by freeze-drying method. In the present work, the physico-chemical properties of scaffolds are evaluated by XRD and FTIR. The interior morphology as well as porous structure are evaluated by scanning electron microscope (SEM). The porosity of scaffolds is examined by mercury intrusion porosimetry (MIP). Additionally, compressive stress parameter is also determined by Instron Industrial Product (Model 3345; Norwood, MA, USA).The respective nanocomposite scaffolds are tested for in vitro Hepg2 cancer cytotoxicity. The nanocomposite scaffolds exhibit good biocompatibility and exerts no toxic effect on Hepg2 liver cancer cell. Therefore, the prepared porous system of nanocomposite scaffolds can be considered as promising technique for tissue engineering.
\end{abstract}

Key words: Dicalcium phosphate; dextran; nanocomposite; 3D Scaffold.

\section{Introduction}

Scaffold plays a unique role in tissue regeneration and repair. During the past two decades, many works have been done to develop potentially applicable scaffold materials for tissue engineering. Scaffolds are defined as 3D porous solid biomaterials designed to perform some or all of the following functions: (i) Promote cell-biomaterial interactions, cell adhesion, and extra cellular matrix (ECM) deposition, (ii) Permit sufficient transport of gases, nutrients, and regulatory factors to allow cell survival, proliferation, and differentiation, (iii) Biodegrade at a controllable rate that approximates the rate of tissue regeneration under the culture conditions of interest, and (iv) Provoke a minimal degree of inflammation or toxicity in vivo ${ }^{(1)}$.

Liver cancer is the third leading cause of cancer deaths globally due to its high incidence and the lack of effective treatments. In the United States, it is now among the 10 most common cancers, and its prevalence has been increased dramatically in the recent years ${ }^{(2)}$. Most primary liver cancer begins in hepatocytes (liver cells). Hepg2 is a cell line derived from the liver tissue of a patient with hepatocellular carcinoma (HCC).

Nanocomposites are a combination of different materials, where at least one dimension of the system is in the nanoscale being less than or equal to $100 \mathrm{~nm}$. Much work has focused on the construction of nanocomposites due to the structural enhancements in physico-chemical properties, and functionality for any given system (3), (4). The interconnected-porous structures of composite can be easily formed by freeze-drying or lyophilizing from composite solution. The interconnected porous structure is very important, so that numerous cells can be seeded and migrated

Correspondsing author: asmaa.mohamed@live.com

DOI : 10.21608/ejbbe.2018.2743.1013

CThe Nathional Information and Documentation Center (NIDOC) 
into the inside. Besides, sufficient amounts of nutrient can be passed through the interconnected pores in a consequence of enhancing cell proliferation or tissue regeneration.

Carboxymethyl cellulose (CMC) is an anion polysaccharide obtained from the carboxymethylation of natural cellulose. In contrast to the cellulose, CMC is a kind of hydrophilic polymers which is easily solubilized in water and has excellent water swelling ability. Furthermore, CMC possesses biocompatible property, low toxicity, low immunogenicity, and biodegradability. These advantageous characteristics make CMC to be attractive polymer for various applications such as food, cosmetics, pharmaceutics, tissue engineering, and drug delivery system ${ }^{(5)}$. On the other hand, Dextran is widely used for biomedical applications due to its biocompatibility, low toxicity and relatively low cost ${ }^{(6)}$. Additionally, Dicalcium phosphate (DCP; $\mathrm{CaHPO}_{4}$ ) powder has proven to be biocompatible and biodegradable when implanted in vivo ${ }^{(7)}$.

The objective of the present work is to generate porous scaffolds, by a combination of biodegradable materials; namely CMC, dextran and/or dicalcium phosphate nanoparticles for biomedical applications. The scaffolds should possess adequate mechanical strength and biodegradation without any undesirable byproducts. Among different materials, CMC-Na and dextran have been chosen as biopolymers and DCP nanoparticles as bioceramic for formation of 3D mechanically stable porous nanocompsite scaffolds. This will provide oxygen and nutrients to flow through the open interconnected pores using simple, low cost freeze drying method. Moreover, the cell cytotoxicity conducted to Hepg2 cancer cells.

\section{Materials and methods}

\section{Materials}

Carboxymethyl cellulose sodium salt (CMC$\mathrm{Na}$ ) powder is purchased from Lobal Chemie with extra purity and medium viscosity (250$350 \mathrm{cps}$ ). Dextran powder from Leuconostoc spp. is purchased from Sigma-Aldrich with molecular weight 15,000-25,000. Dicalcium phosphate nanoparticles $<20 \mathrm{nms}$ (DCP) powder is purchased from [Nanostreams - Egypt, NS0004].

Synthesis

The composite scaffolds are prepared by freeze drying technique. Scaffold samples are made with cylindrical forms as shown in Fig.1. Initially, the dextran and $\mathrm{CMC}-\mathrm{Na}$ are successively mixed in distilled water $(10 \% \mathrm{w} / \mathrm{v})$ till viscous solution is obtained. Thereafter, DCP powder is dispersed in the polymer solution for 1 hour at room temperature. The resulted homogenous nanodispersions formed are poured in Elisa 24 well plate and kept in freezer at $-4^{\circ} \mathrm{C}$ for 48 hours. Finally samples are lyophilized in a freeze dryer for 48 hours at $-92^{\circ} \mathrm{C}^{(\mathbf{8})}$. The lyophilized scaffolds are collected and kept in a desiccator for further characterization. The compositions of samples are listed inTable1.

TABLE 1. The chemical composition of nanocomposite scaffolds (wt.\%).

\begin{tabular}{cccc}
\hline Sample code & CMC-Na\% & Dextran\% & DCP\% \\
\hline S1 & 50 & 50 & 0 \\
S2 & 50 & 25 & 25 \\
S3 & 37 & 18 & 45 \\
\hline
\end{tabular}

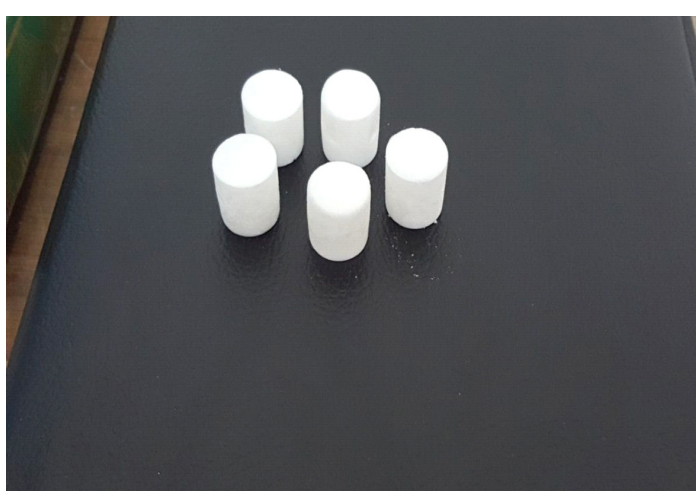

Fig. 1. The freeze-dried spongy structure scaffold samples of cylindrical forms.

\section{Characterization}

$\mathrm{X}$-ray diffraction analysis is performed by $\mathrm{X}$-ray diffractometer, using Ni-filtered $\mathrm{CuK} \alpha$ irradiation ( $\lambda=1.54 \AA$ ) at $40 \mathrm{kV}$ and $25 \mathrm{~mA}$ with scanning rate $0.1^{\circ}$ in the $2 \theta$ ranging from 10 to $80^{\circ}$ step time per s. FTIR spectra are recorded on (Jasco model 4600) FTIR spectrometer in 4000 $400 \mathrm{~cm}^{-1}$ region and samples are pressed into small pellets by pressing the scaffold powder with $\mathrm{KBr}$. The surface morphology and pore diameter of scaffolds are examined as well by scanning electron microscope (SEM) model Quanta 250 FEG (Field Emission Gun), with accelerating voltage $30 \mathrm{kV}$, magnification up to 1000000 
and resolution for Gun.1n). SEM analyses are performed on a thin piece of the nanocomposite scaffold cut using a sharp razor blade. SEM micrographs are obtained after coating the samples with Gold using K550X sputter coater. The median pore diameter, density and percent porosity measured with mercury intrusion porosimetry (MIP). The compressive strength of the scaffolds is measured using (Model 3345; Instron Industrial Products) with a load cell of $5 \mathrm{kN}$ and data are recorded using computer software (Instron ${ }^{\circledR}$ Bluehill Lite). Then the samples are statically loaded (in compression manner) using stainlesssteel rod ended with flat plate $(40 \mathrm{~mm} \times 60 \mathrm{~mm})$ attached to the upper movable compartment of the machine at a crosshead speed of $0.5 \mathrm{~mm} / \mathrm{min}$. The compressive strength of nanocomposite scaffolds are calculated using the following equation;

Where (CS) is compressive strength, $(\mathrm{P})$ is the load $(\mathrm{N})$ at the fracture point and (d) is the diameter of the scaffold.

MTT assay for human hepatocellular carcinoma

Human hepatocellular carcinoma (Hepg2) was purchased from American type cell culture collection and were grown on Dulbecco's modified eagle's medium (DMEM) ${ }^{(9)}$, it is supplemented with $1 \%$ of $100 \mathrm{mg} / \mathrm{mL}$ of streptomycin, 100 units/ $\mathrm{mL}$ of penicillin and $10 \%$ of heat-inactivated fetal bovine serum in a humidified, $5 \%(\mathrm{v} / \mathrm{v}) \mathrm{CO}_{2}$ atmosphere at $37^{\circ} \mathrm{C}$. The cell cytotoxicity of the prepared scaffolds is assessed using MTT (3-(4,5-dimethylthiazol-2yl)-2,5-diphenyltetrazolium bromide) assay.

In MTT assay, exponentially growing cells from different cancer cell lines are trypsinized, counted and seeded at the appropriate densities (2000-1000 cells $/ 0.33 \mathrm{~cm}^{2}$ well) into 96well microtiter plates. Moreover, the cells are incubated in a humidified atmosphere at $37^{\circ} \mathrm{C}$ for $24 \mathrm{~h}$ and exposed to different concentrations of the nanocomposites for $72 \mathrm{~h}$. The viability of treated cells is determined using MTT technique as follow. Media were removed; cells were incubated with $200 \mu \mathrm{l}$ of 5\% MTT solution/well (Sigma Aldrich, $\mathrm{MO}$ ) and were allowed to metabolize the dye into colored-insoluble formazan crystals for 2 hours. The remaining MTT solution were discarded from the wells and the formazan crystals were dissolved in $200 \mu \mathrm{l} / \mathrm{well}$ acidified isopropanol for $30 \mathrm{~min}$, covered with aluminum foil and with continuous shaking using a MaxQ 2000 plate shaker (Thermo Fisher Scientific Inc, MI) at room temperature. Absorbance was measured at $570 \mathrm{~nm}$ using a epoch-2C spectrophotometer (Bio TekVT). Viability percentage is calculated as follows: Cell viability percentage $=(\mathrm{OD}$ of treated cells $/$ OD of untreated cells) X $100^{(10)}$.

\section{Results and discussion}

$X$-Ray Diffraction Analysis

XRD pattern in Fig. 2 shows well crystalline dicalcium phosphate - Monetite phase $\left(\mathrm{Ca}_{4} \mathrm{P}_{4}\right.$ $\mathrm{O}_{16} \mathrm{H}_{4}$ ). The mineral structure is confirmed by the TEM results in Fig.3 with fine uniform spherical nanoparticles of Monetite less than $20 \mathrm{nms}$.

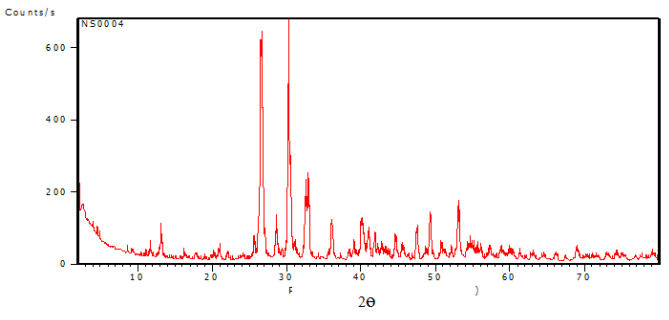

Fig. 2. XRD analysis of dicalcium phosphate.

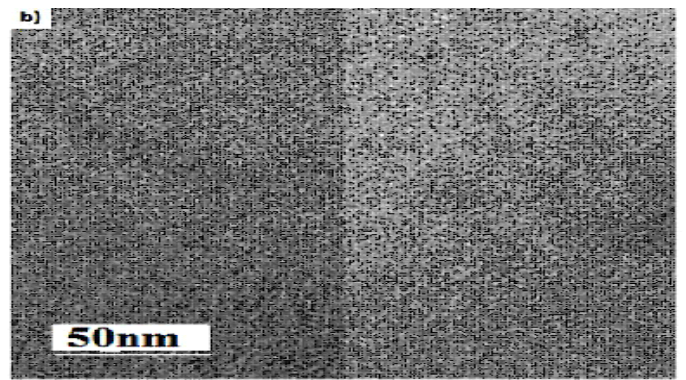

Fig. 3. TEM of dicalcium phosphate nanoparticles.

The XRD diffraction pattern of the nanocomposite scaffolds of S1, S2 and S3 are displayed in Fig.4. S1 exhibits a diffraction hump between $2 \theta=15$ to $20^{\circ}$ corresponding to dextran ${ }^{(11)}$ and this hump is probably overlapped with CMCNa hump ${ }^{(12)}$.

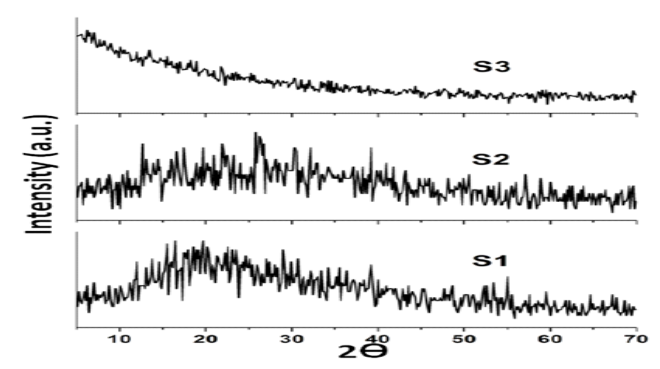

Fig. 4. XRD patterns of nanocomposite scaffolds. 
According to the XRD results, it is confirmed that the presence of DCP in S2 and S3 doesn't change the obtained amorphous phase by combing dextran and CMC-Na. The XRD results suggest a complete entrapment of DCP into the matrix of CMC-Na and dextran.

\section{FTIR analysis}

The FTIR data of the nanocomposite scaffolds are presented in Fig.5. The band at $3409 \mathrm{~cm}^{-1}$ is corresponding to the stretching frequency of the $-\mathrm{OH}$ group. The band around $2919 \mathrm{~cm}^{-1}$ is due to $\mathrm{C}-\mathrm{H}$ asymmetrical stretching vibration in methyl group. The presence of a strong absorption bands at 1600 and $1415 \mathrm{~cm}^{-1}$ are due to the asymmetric and symmetric stretching of COOgroup, respectively. The band around $1324 \mathrm{~cm}^{-1}$ is assigned to $-\mathrm{OH}$ bending vibration. The band at
$1064 \mathrm{~cm}^{-1}$ is due to $\mathrm{CH}-\mathrm{O}-\mathrm{CH}_{2}$ stretching (13), (14). The additional band is observed at wavenumber of $2370 \mathrm{~cm}^{-1}$ might be due to the existence of some impurities overlapped with water band as reported by Saputra et al ${ }^{(15)}$. The band at $2157 \mathrm{~cm}^{-1}$ is due to carbon-carbon triple bond $(-\mathrm{C} \equiv \mathrm{C}-$ stretch). The absorption band at $1737 \mathrm{~cm}^{-1}$ is refered to $\mathrm{C}=\mathrm{O}$ saturated ester stretching band ${ }^{(16)}$. C-O-C glycosidic ether band at $1120 \mathrm{~cm}^{-1}$ arises from the polysaccharide components is observed in all the spectra as early reported by Garside and Wyeth (17). The absorption bands between 1010 and 1267 $\mathrm{cm}^{-1}$ are characteristic of the $-\mathrm{C}-\mathrm{O}-$ stretching in polysaccharide skeleton. The wavenumber of about $896 \mathrm{~cm}^{-1}$ associated with the $\beta-(1,4)$ glycosidic linkages between the glucose units in cellulose of S1, Viera et al ${ }^{(18)}$.

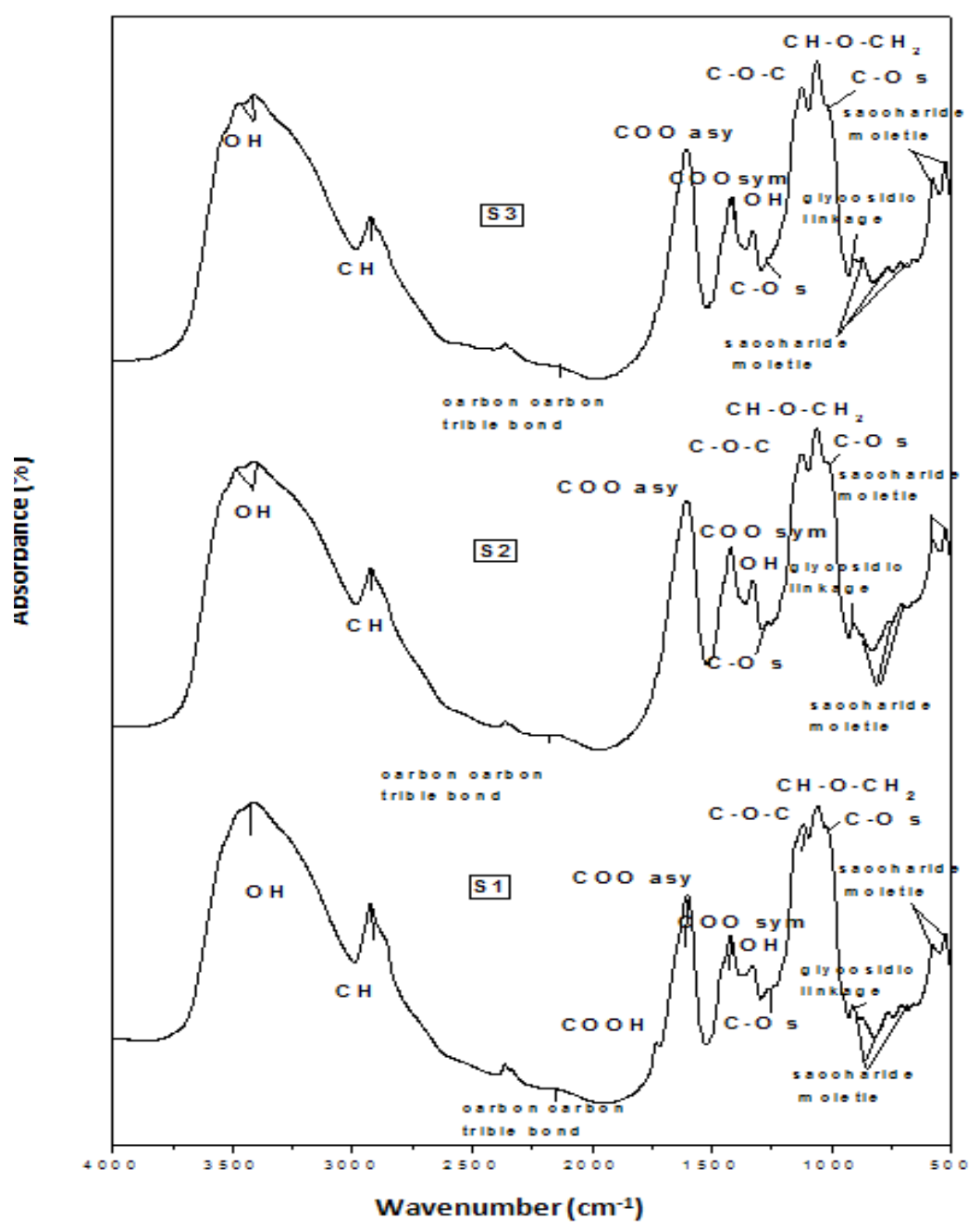

Fig. 5. FTIR spectra of $s 1, s 2$ and $s 3$ composite scaffolds. 

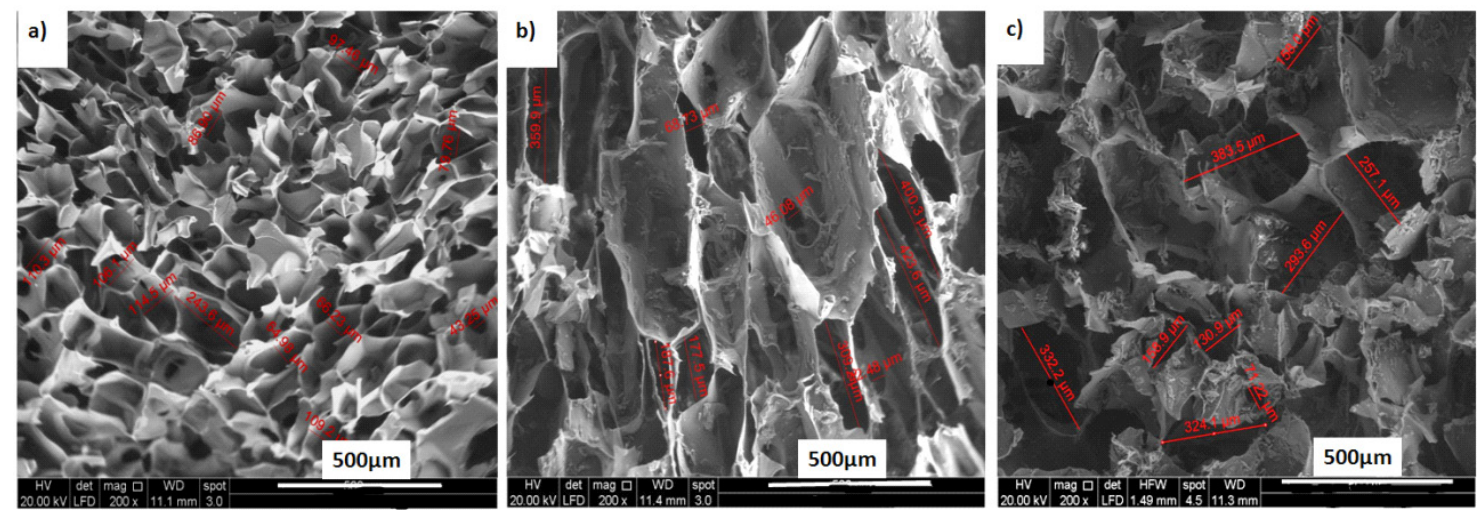

Fig. 6. SEM micrographs of a)S1, b)S2 and c)S3 composite scaffolds at same magnification.

Bands around $520-875 \mathrm{~cm}^{-1}$ give clue about the presence of saccharide moietie ${ }^{(19)}$. The FTIR bands at the region $520-875 \mathrm{~cm}^{-1}$ are 518,580 , 698 and $757 \mathrm{~cm}^{-1}$ for S1, 520, 582, 719 and 767 $\mathrm{cm}^{-1}$ for S2 and 518, 568, 661, 713 and $875 \mathrm{~cm}^{-1}$ for S3. Mario et al ${ }^{(20)}$ had found that the carboxyl groups and their salts wavenumbers were at 1600$1640 \mathrm{~cm}^{-1}$ and $1400-1450 \mathrm{~cm}^{-1}$ respectively which represented the fingerprint region for CMC-Na. The interaction mechanism between CMC-Na and dextran could be explained as follow; the hydroxyl and carboxyl groups of CMC-Na can form strong hydrogen bonds (21) and also ester bonds ${ }^{(22)}$ with the hydroxyl groups on dextran, thus improve the interactions between molecules, which lead to preferred cohesiveness of the bipolymer matrix. The appearance of absorption band at $1737 \mathrm{~cm}^{-1}$ in S1 is also a clear indication of the complex formation.

Additionally, the band that is observed for S2 and $\mathrm{S} 3$ at $3401 \mathrm{~cm}^{-1}$ may be due to the presence of DCP. Also the disappearance of absorption band at $1737 \mathrm{~cm}^{-1}$ and shifting of bands for S2 and S3 referred to intermolecular interaction between biopolymer and DCP. FTIR results suggest a possible interaction between CMC-Na and dextran by either hydrogen or ester bonds. Also there is a possible interaction between DCP and the biopolymer matrix through the hydrogen bonds.

\section{Morphological and microstructural properties}

SEM micrographs of experimental scaffolds reveal a foam-like scaffold structure consisting of a polymer or composite skeleton with micropores ranging from $40 \mu \mathrm{m}$ to $500 \mu \mathrm{m}$. The composite scaffolds possess complicated irregular interconnected porous structures as shown in
Fig.6. Moreover, S1 shows smoother pore walls and smaller pores when compared with S2 and $\mathrm{S} 3$, and this is due to the presence of DCP.

Comparing the $\mathrm{CMC} / \mathrm{DEX}$ and $\mathrm{CMC} / \mathrm{DEX} /$ DCP nanocomposite scaffolds, it can be seen that the porosity of the CMC/DEX/DCP scaffolds are lower than the CMC/DEX composites. The MIP results are also obtained in Table 2. The reason may be that the dicalcium phosphate occupies space of ice in the frozen mixture resulting in a lower porosity in $\mathrm{CMC} / \mathrm{DEX} / \mathrm{DCP}$ nanocomposite scaffolds. In addition, the CMC/DEX/DCP nanocomposite scaffolds have better ideal porous structure with majority of pore diameter being of 40 to $500 \mu \mathrm{m}$, which may be helpful to promote cell adhesion and conductive tissue growth with a good nutrient delivery to the site of tissue regeneration ${ }^{(23)}$.

TABLE 2 the microstructure properties of experimental scaffolds.

\begin{tabular}{lccc}
\hline $\begin{array}{l}\text { Sample } \\
\text { name }\end{array}$ & $\begin{array}{c}\text { Porosity } \\
(\mathbf{\%})\end{array}$ & $\begin{array}{c}\text { Median pore } \\
\text { diameter } \\
\text { (diameter } \\
\boldsymbol{\mu m})\end{array}$ & $\begin{array}{c}\text { Skeletal } \\
\text { density } \\
(\mathbf{g} / \mathbf{m l})\end{array}$ \\
\hline S1 & 79.11 & 65.68 & 1.1688 \\
S2 & 66.10 & 60.46 & 1.8908 \\
S3 & 68.61 & 163.41 & 0.3915 \\
\hline
\end{tabular}

The interfacial bonding between the two phases is an important consideration for nanocomposite. The apparent density of nanocomposite increases with increasing DCPD content in S2 while diminish in S3 and this may be due to that there is no interfacial bonding happens between polymer and DCPD ${ }^{(24)}$. Moreover, the expected enhancement in apparent density and 
drop in pore diameter in S3 is due to enhancement of DCPD concentration which is countered by suppression in concentration of $\mathrm{Na}-\mathrm{CMC}$ and dextran. It is observed that increment of porosity and pore diameter of S3 is connected with enhancement of DCP concentration. This is in agreement with the research performed by other authors Kim et al ${ }^{(25)}$ and He et al ${ }^{(26)}$. These data suggest that DCP is not embedded within the polymer during preparation of $\mathrm{S} 3$ as effectively as the $\mathrm{S} 2$, and this may enhance ions resulting from DCP dissolution to surrounding cells (27). The increase in porosity and in pore diameter in S3 when DCP concentration is increased may be also due to DCP residual space ${ }^{(28)}$. Additionally, the pore diameter distribution of scaffold is regretted with the enhancement of DCP concentration in S2 and return to grows in S3 as shown in Fig.7 and this confirms the results presented in Table 2.

Although scaffold's porosity is an important factor relating to nutrient transport, other factors may contribute to the success of the implant and cellular response.

\section{Mechanical properties}

The compressive stress of the prepared nanocomposite scaffolds is shown in Fig.8. The mechanical properties and structural integrity of scaffolds are affected by the microstructure properties of the prepared scaffolds such as porosity, pore volume, shape and connectivity. Several fabrication methods have been developed to fabricate $3 \mathrm{D}$ polymer-ceramic scaffolds with controlled porosity. Practically, the solvent in freeze drying method is firstly solidified by freezing. The frozen mixture is then lyophilized using a freeze-dryer, in which the ice sublimes leaving vacant pores (29),(30). The scaffold S2 exhibits higher compressive stress when comparing with S1 and S3 scaffolds. This result could be explained owe to the presence of DCP as well as higher percentage of $\mathrm{CMC}-\mathrm{Na}$. This initiates intermolecular forces in dextran and $\mathrm{CMC}-\mathrm{Na}$ as well as in DCP. On the other hand, the brittleness of ceramic isn't avoided by combining DCP with the biopolymer as in case of S3. The depletion of the compressive stress of S3 composite scaffold may be due to increment DCP percentage depending on the amount of CMC-Na. Moreover, the lower compressive stress is attributed to the bigger pore sizes in S3 together with the increase of DCP content associated with the depletion of CMC-Na and dextran amounts ${ }^{(31),(32)}$.

In vitro cell cytotoxicity

The in vitro cytotoxicity effect of S1, S2 and S3 scaffolds on Hepg2 cells is evaluated by MTT assay. Fig. 9 shows that the viabilities of Hepg 2 cells treated with S1, S2 and S3 scaffolds for $72 \mathrm{~h}$ are over $70 \%$. These results suggest that all S1, S2 and S3 have low cytotoxicity and can be considered safe for clinical use. Since dextran and $\mathrm{Na}-\mathrm{CMC}$ polymers are polysaccharides, they exert no toxic effect on Hepg 2 cancer cells. Also the release of calcium, phosphorus and sodium ions from the scaffolds within the normal limit in human body confirms the MTT assay.

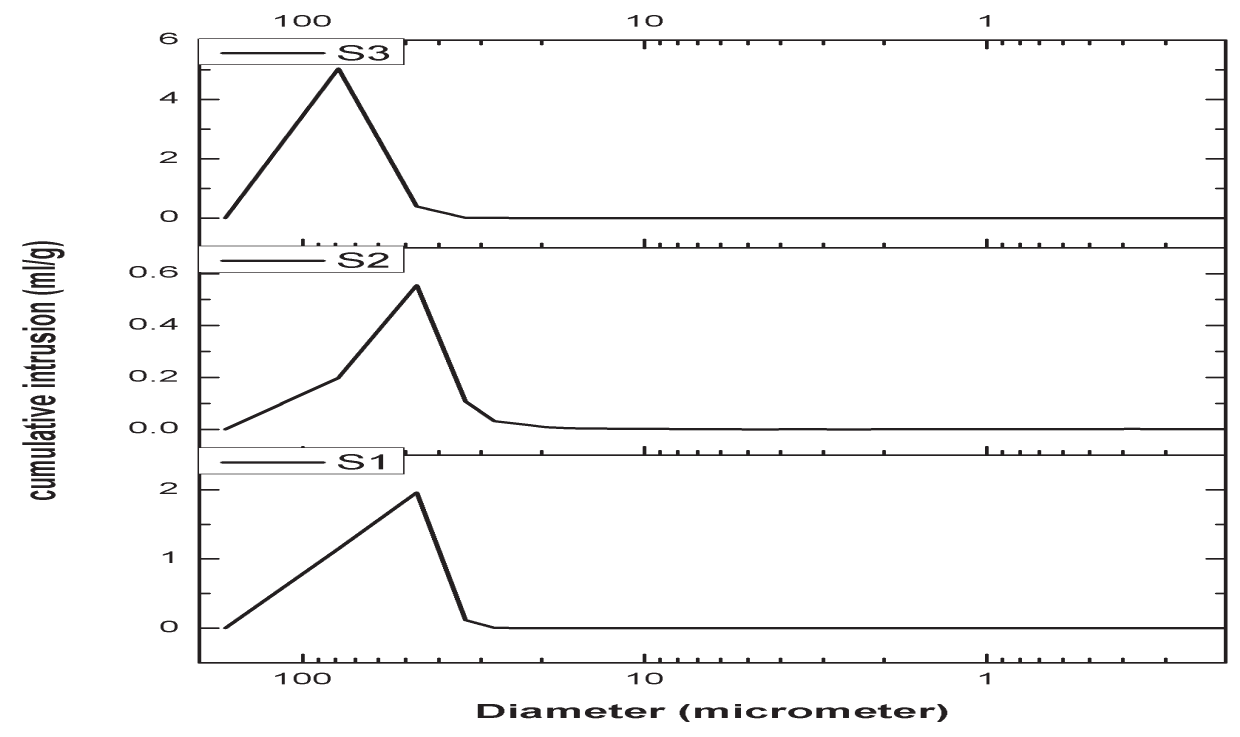

Fig. 7 . The pore diameter distribution of S1, S2, S3 nanocomposite scaffolds. 


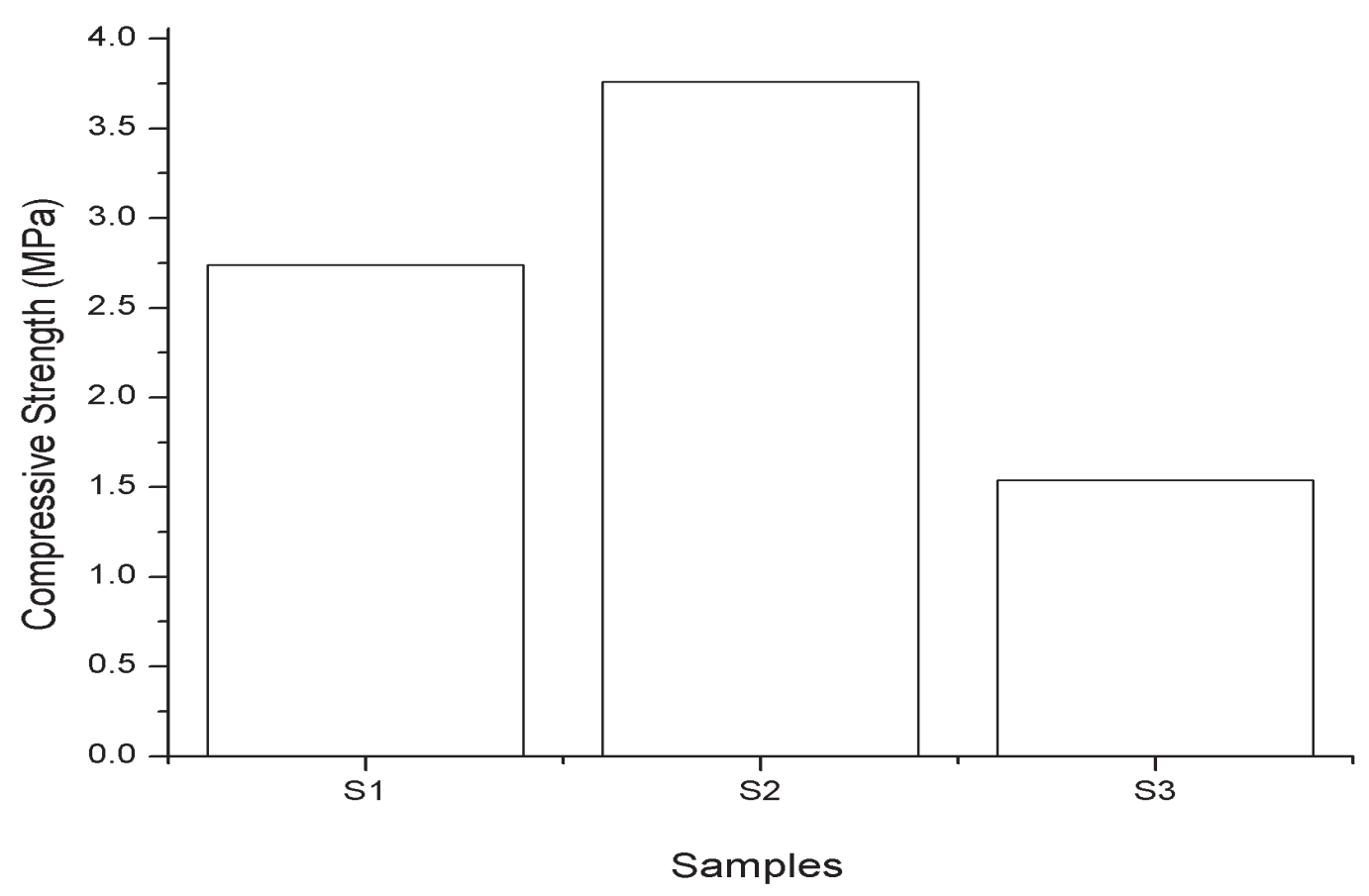

Fig. 8. Compressive stress of experimental scaffolds S1, S2 and S3.

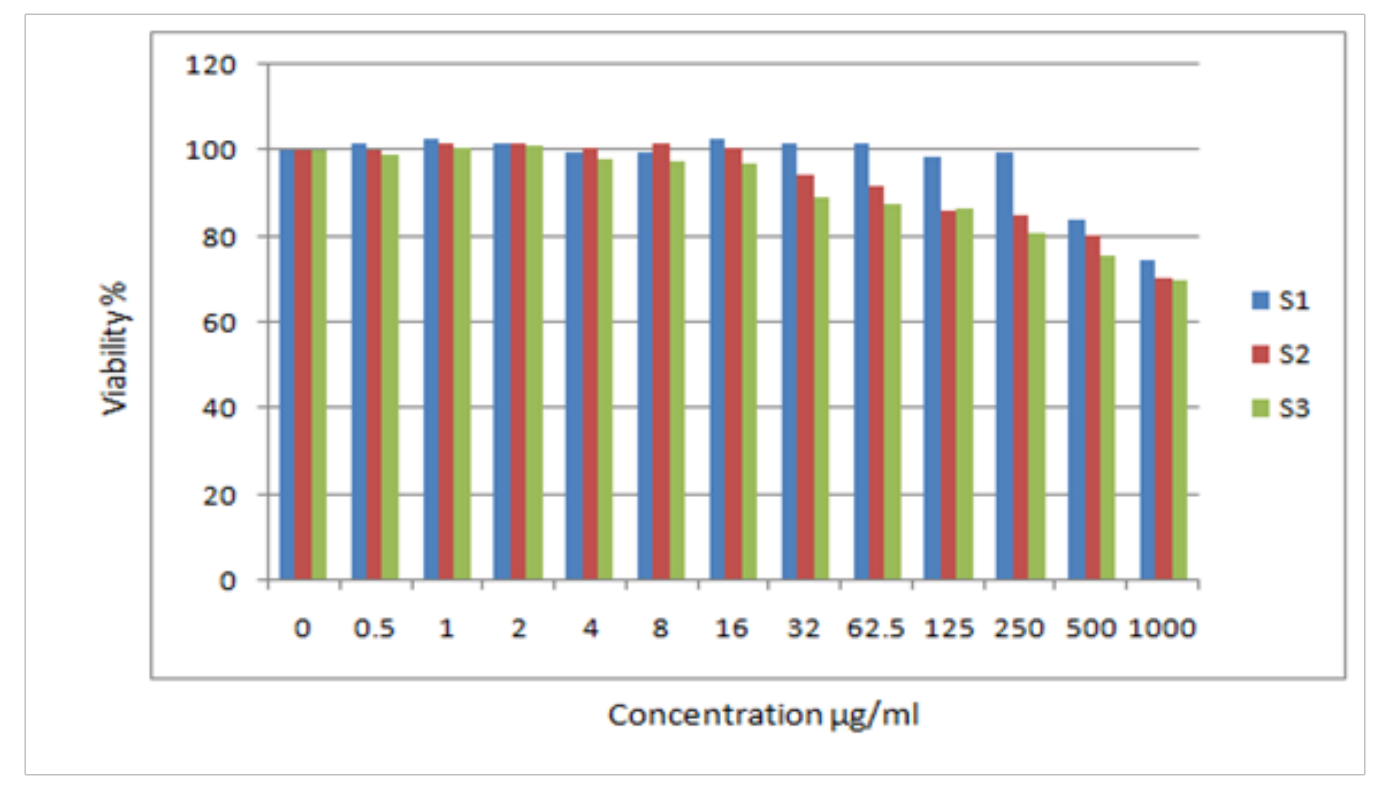

Fig. 9. Cytotoxicity effect of S1,S2 and S3 scaffolds on Hepg2 cancer cell 


\section{Conclusion}

- Nanocomposite scaffolds based on dicalcium phosphate nanoparticles together with dextran and carboxymethyl cellulose polymers are processed successfully in cylindrical forms by lyophilization process.

- Complete entrapment of DCP into the matrix of CMC-Na and dextran at certain percentage 25 and 45.

- There is a possible interaction between CMC$\mathrm{Na}$ and dextran by either hydrogen or ester bonds. Also there is a possible interaction between DCP and the bipolymer matrix through the hydrogen bonds.

- SEM micrographs reveale irregular interconnected porous structures consisting of a polymer or composite skeleton with micropores ranging from 40 to $500 \mu \mathrm{m}$. When the DCP concentration in the scaffold is increased, this will lead to enhancement of sample's roughness.

- The CMC/DEX/DCP nanocomposite scaffold have ideal porous structure, the majority being in the diameter limit of 40 to $500 \mu \mathrm{m}$, which may be helpful to promote cell adhesion and conductive tissue growth by delivery of good nutrient to the site of tissue regeneration.

- The nanocomposite scaffolds with 79\% network porosity exhibit enhanced compressive stress (3.76 MPa).

- The nanocomposite scaffolds exhibit good biocompatibility and exerts no toxic effect on Hepg2 liver cancer cell.

\section{$\underline{\text { References }}$}

1. Langer R. and Tirrell D. A., "Designing materials for biology and medicine", Nature, 428, 487-492, (2004).

2. Siegel R., Naishadham D. and Jemal A., "Cancer statistics”, CA: Cancer J Clin, 62,10-29, (2012).

3. Poursamar, S. A., Azami, M. and Mozafari, M., "Controllable Synthesis and Characterization of Porous Polyvinyl Alcohol/Hydroxyapatite Nanocomposite Scaffolds via an in Situ Colloidal Technique",Colloids and Surfaces B: Biointerfaces, 84, 310-316, (2011).

4. Hamlekhan, A., Moztarzadeh, F., Mozafari, M., Azami, M. and Nezafati, N., "Preparation of Laminated Poly( $\varepsilon$-caprolactone)-GelatinHydroxyapatite Nanocomposite Scaffold Bioengineered via Compound Techniques for Bone Substitution". Biomatter, 1, 1-11, (2011).
5. Tippawan Siritientong and Pornanong Aramwit, "Characteristics of Carboxymethyl Cellulose/ Sericin Hydrogels and the Influence of Molecular Weight of Carboxymethyl Cellulose", Macromolecular Research, 23, 861-866, (2015).

6. Mehvar R., "Dextrans for targeted and sustained delivery of therapeutic and imaging agents", $J$ Control Release, 69, (2000).

7. Kodaka T., Kobori M., Hirayama A. and Abe M. ,"Abrasion of human enamel by brushing with a commercial dentifrice containing hydroxyapatite crystals in vitro.", Journal of Electron Microscopy, 48, 167-172, (1999).

8. Liuyun J., Yubao L. and Chengdong X., "Preparation and biological properties of a novel composite scaffold of nano-hydroxyapatite/ chitosan/carboxymethyl cellulose for bone tissue engineering", Journal of Biomedical Science, 16, 1-10, (2009).

9. Cory A.H., Owen T.C., Barltrop J.A. and Cory J.G., "Use of an aqueous soluble tetrazolium/ formazan assay for cell growth assays in culture.", 3 , 207-212, (1991).

10. Chen X., Ping L.,Liu J. and Kangsen X., “Apoptosis of human hepatocellular carcinoma cell (HepG2) induced by cardiotoxin III through S-phase arrest", Exp Toxicol Pathol., 61, 307-315, ( 2009).

11.Yuan W., Geng Y., Wu F., Liu Y., Guo M., Zhao H. and Jin T., "Preparation of polysaccharides glassy microparticles with stabilization of proteins", Int. J. Pharm., 366, 154- 159, (2009).

12. Trabelsi S., Albouy P.A., Impéror-Clerc M., Guillot S. and Langevin D., "X-ray diffraction Study of the structure of carboxymethylcellulose-cationic surfactant complexes", Chemphyschem, 8, 2379$85,(2007)$

13. Qiu H. and Yu, J., "Polyacrylate / (carboxymethylcellulose modified montmorillonite) superabsorbentnanocomposite", Journal of Applied Polymer Science, 107, 118-123. (2008).

14. Ma, J., Xu, Y., Fan, B. and Liang, B., "Preparation and characterization of sodium carboxymethylcellulose/ poly (N-isopropylacrylamide) / clay semi-IPN nanocomposite hydrogels" , European Poylmer Journal, 43, 2221-2228, (2007).

15. Saputra A., Qadhayna L. and Badra Pitaloka A., "Synthesis and Characterization of Carboxymethyl Cellulose (CMC) from Water Hyacinth Using Ethanol-Isobutyl Alcohol Mixture as the Solvents", International Journal of Chemical Engineering and Applications, 5, 36-40, (2014).

Egypt. J. Biophys. Biomed. Eng., Vol. 18 (2017) 
16. Edgar K. J., Buchanan C. M., Debenham J. S., Rundquist P. A., Seiler B. D. and Shelton M. C., "Advances in cellulose ester performance and application", Progress in Polymer Science, 26, 1605-1688, (2001).

17. Garside P. and Wyeth P., "Identification of cellulosic fibres by FTIR spectroscopy: Thread and single fibre analysis by attenuated total reflectance", Studies in Conservation, 48, 269-275 (2003).

18. Viera R.G.P., Filho G.R., Assuncao R.M.N., Meireles C.S.,Vieira J.G. and Oliveira G.S., "Synthesis and characterization of methylcellulose from sugar cane bagasse cellulose", Carbohydrate Polymers, 67, 182-189,(2007).

19. Nataraj S., Schomäcker R., Kraume M., Mishra I.M. and Drews A., "Analyses of polysaccharide fouling mechanisms during crossflow membrane filtration", J. Membr. Sci., 308, 152-161, (2008).

20. Mario P., Adinugrada D.W. and Haryadi M., "Synthesis and characterization of sodium carboxylmethylcellulose from Cavendish banana pseudo stem (Musa cavendishii LAMBERT)." Carbohydr. Polym., 62, 164-169, (2005).

21. Ghanbarzadeh B., Almasi H. and Entezami A.A., "Physical properties of edible modified starch/ carboxymethyl cellulose films", Innov Food Sci Emerg, 11, 697-702, (2010).

22. Li Y., Shoemaker C.F., Ma J., Shen X. and Zhong F., "Paste viscosity of rice starches of different amylose content and carboxymethylcellulose formed by dry heating and the physical properties of their films", Food Chem, 109, 616-623,(2008).

23. Oh, S. H., Park, I. K., Kim, J. M. and Lee J. H., "In vitro and in vivo characteristics of PCL scaffolds with pore size gradient fabricated by a centrifugation method", Biomaterials, 28, 16641671, (2007).

24. Liu Q., de Wijn J. and van Blitterswijk C.A., "Composite biomaterials with chemical bonding between hydroxyapatite filler particles and PEG/ PBT copolymer matrix". Journal of Biomedical Materials Research, 40, 490-497, (1998).

25. Kim S.S., Ahn K.M., Park M.S., Lee J.H., Choi C.Y. and Kim B.S., "A poly(lactide coglycolide)/ hydroxyapatite composite scaffold with enhanced osteoconductivity", J. Biomed. Mater. Res. A, 80, 206-215, (2007).

26. He J., Genetos D.C. and Leach J.K., "Osteogenesis and trophic factor secretion are influenced by the composition of hydroxyapatite/poly(lactide-coglycolide) composite scaffolds", Tissue Eng. Part A, 16, 127-137,(2010).

Egypt. J. Biophys. Biomed. Eng., Vol. 18 (2017)
27. Hoppe A., Guldal N.S. and Boccaccini A.R. "A review of the biological response to ionic dissolution products from bioactive glasses and glass-ceramics", Biomaterials, 32, 2757-2774, (2011).

28. Fu Y.C., Chen C.H., Wang C.Z., Wang Y.H., Chang J.K., Wang G.J., Mei-Ling Ho and Wang C.K., "Preparation of porous bioceramics using reverse thermo-responsive hydrogels in combination with rhBMP-2 carriers: In vitro and in vivo evaluation", journal of the mechanical behavior of biomedical materials, 27, 64-76,(2013).

29. Boccaccini A. R. and Maquet, V., "Bioresorbable and Bioactive Polymer/BioglassR Composites with Tailored Pore Structure for Tissue Engineering Applications", Comp. Sci. Technol., 63, 2417-2429, (2003)

30. Maquet R. and Jerome R. "Design of Macroporous Biodegradable Polymer Scaffolds for Cell Transplantation", Mat. Sci. Forum, 250, 15-42, (1997).

31. Luchini and Timothy John, "Development of high strength dicalcium phosphate anhydrous cement with nanosilica sol", Theses and Dissertations, P. $368,(2012)$.

23. Burdick J.A., Frankel D., Dernell W.S. and Anseth K.S. "An initial investigation of photocurable three-dimensional lactic acid based scaffolds in a critical-sized cranial defect", Biomaterials, 24, 1613-20, (2003). 


\section{تأثثير دعامات مركبات النانو المحضره باستخدام تقتية التجمد الجاف على خلايا الكبد \\ (السرطانيه}
محمد اسماعيل الجوهرى *" "جيهان محمد كمال **,عماد عبد السلام المليجى ***,سحر محمد عوض **"أسماء

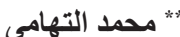 قسم الفيزياء-شعبة الفيزياء الحيويه_كلية العلوم (بنين)-جامعة الأز هر -مدينة نصر ـ القاهره

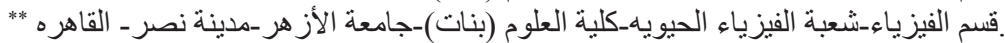

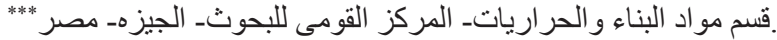 يوجد توجه جديد نحو تخليق دعامات ثثلاثية الأبعاد تسمح بنفاذية وانتشار متميز للمو اد المختلفه. المو اد المصنعه

و القابله للتحلل المناسبه لهذا الغرض هى مركبات النانو المكونه من السير اميك و البوليمر الحيوى و هذه المركبات لديها تو افق حيوى جيد للأنسجه المحيطه بهاو مو اصفات الميات امنه تبدو أساسيه للاستخدام الملائم فى التطبيقات الطبيه. تم اعداد مركبات

dicalcium phosphate/dextran/ sodium carboxymethyl cellulose الجاف(freeze-drying ). ثم تم قياس الخو اص الكيميائيه والفيزيائيه للاعامات المصنعه من مركبات النانو

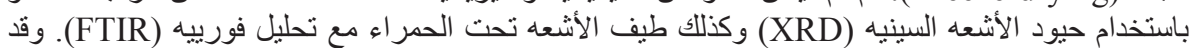

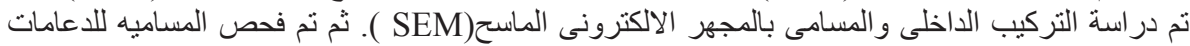

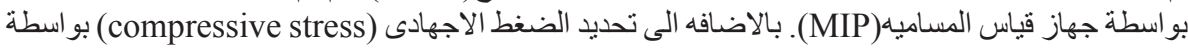

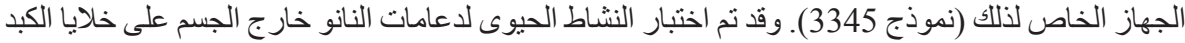

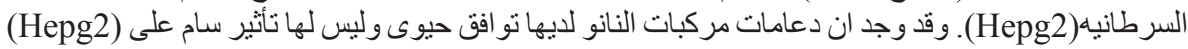
وبالتالى يمكن استخدامها فى التطبيقات الطبيه. 